\title{
STUDI PERSEPSI TERHADAP ASPEK-ASPEK KESEHATAN PADA DESAIN KAMAR MANDI HUNIAN SEWA Studi Kasus: Kos-kosan di Sekitar Kampus ITB
}

\author{
Feni Kurniati $^{1)}$, Nurhijrah ${ }^{2)}$ \\ ${ }^{1}$ Dosen SAAPK Institut Teknologi Bandung, \\ ${ }^{2}$ Dosen Program Studi Teknik Sipil, Universitas Andi Djemma, Palopo \\ 1)fenikurniati@gmail.com \\ ${ }^{2)}$ nurhijrahbakri@yahoo.com
}

\begin{abstract}
Abstrak
Kamar mandi merupakan salah satu unit ruang yang sangat penting dalam sebuah hunian. Selain aspek fungsi tersebut, kamar mandi juga seharusnya didesain untuk memenuhi ketentuan-ketentuan yang terkait dengan aspek kesehatan. Tulisan ini bertujuan untuk melihat tingkat kelayakan kamar mandi di hunian sewa kos-kosan mahasiswa ITB, melalui studi persepsi penggunanya. Data dikumpulkan melalui kuesioner yang disebar secara online kepada 35 responden. Pertanyaan kuesioner dibagi ke dalam dua kategori, yaitu pertanyaan terkait 'layak' dan 'tidak layak' dan pertanyaan terkait tingkat kepuasan responden. Penelitian ini menunjukkan bahwa lebih dari $60 \%$ responden menyatakan bahwa kamar hunian kos-kosan mereka telah memenuhi checklist kelayakan kamar mandi sehat. Akan tetapi, ditemukan adanya ketidak sesuaian dengan tingkat kepuasan responden terhadap kondisi kamar mandi tersebut. Penelitian ini juga menunjukkan bahwa perlunya dilakukan telaah lebih lanjut terkait aspekaspek kesehatan yang diterapkan dalam desain hunian sewa kos-kosan mahasiswa untuk menjamin kesehatan penghuninya.
\end{abstract}

Kata Kunci: Desain, hunian sewa kos-kosan, kamar mandi, kesehatan

\section{PENDAHULUAN}

Kamar mandi merupakan salah satu ruang yang memiliki peran sangat penting dalam sebuah hunian, karena ia menampung berbagai jenis aktifitas dari penghuninya (Kusumarini \& Utomo, 2008). Menurut penelitian Kira (dalam Harisah 2013) kamar mandi mampu menampung 30 fungsi di dalamnya. Sedangkan penelitian Harisah (2013), yang dilakukan terhadap penghuni hunian sewa kos-kosan, ditemukan bahwa terdapat 17 jenis kegiatan membersihkan diri yang dilakukan oleh penghuninya di dalam kamar mandi. Hal ini menjunjukkan bahwa keberadaan kamar mandi dalam sebuah hunian menjadi sangat penting untuk diperhatikan agar fungsinya dapat terpenuhi dengan baik.

Untuk menjaga kelangsungan fungsi vital kamar mandi tersebut, maka dibuat ketentuan-ketentuan yang mengatur kelayakan desain kamar mandi. Ketentuanketentuan ini tidak hanya terkait dimensi teknis (fisik), namun juga dimensi kenyamanan dari segi kesehatan Kumar \& Taunk, 2010). Hal ini menjadi penting karena kamar mandi merupakan ruang basah yang bersifat lembab, yang menjadi ruang tempat berlangsungnya berbagai "ritual pembersihan" (Murtini, et.al., 1994).

Terpenuhinya kriteria-kriteria sehat sebuah kamar mandi tersebut tidak hanya dipengaruhi oleh kesadaran penghuni akan pentingnya kualitas kamar mandi. Akan tetapi juga dipengaruhi oleh faktor kemapuan ekonomi pemilik hunian (Kumar \& Taunk, 2010). Seringkali keterbatasan biaya menyebabkan perhatian terhadap aspek kelayakan kamar mandi menjadi teraabaikan. Isu ini semakin penting jika dilihat dalam konteks hunian sewa, yaitu kos-kosan mahasiswa, yang mana aspek ekonomi menjadi salah satu prioritas. Pertimbangan ekonomi ini sering kali menyebabkan aspek-aspek kesehatan tidak dipenuhi sebagaimana mestinya, khususnya pada kamar 
mandi, yang merupakan salah satu ruang yang menuntut tingkat kesehatan dan kehigienisan yang tinggi.

Berdasarkan penjelasan tersebut, maka penelitian ini disusun untuk melihat bagaimana hubungan tingkat kepuasan pengguna kamar mandi dengan kondisi kamar mandi di hunian sewa kos-kosan mahasiswa, yang dilihat dari kacamata kesehatan diri dan lingkungan penghuninya.

\section{Aspek Kesehatan Dalam Desain Kamar Mandi Di Unit Hunian}

Aspek kesehatan dalam desain kamar mandi menjadi sangat penting untuk dihabas dan distudi lebih lanjut. Hal ini, selain disebabkan oleh pentingnya fungsi kamar mandi dalam memenuhi kebutuhan dasar manusia, seperti buang air besar, buang air kecil, mandi, mencuci dan lainnya, juga disebabkan pentingnya untuk menjaga kehieginisan kamar mandi tersebut agar tidak mencemari ruang lainnya. Kumar dan Taunk (2010) menyebutkan bahwa kamar mandi yang tidak bersih dan tidak higienis sangat beresiko untuk menyebarkan infeksi dan penyakit yang dapat mengganggu kesehatan tubuh baik jangka pendek maupun jangka panjang.

Oleh sebab itu, sebagai sebuah siklus pembuangan, kamar mandi membutuhkan adanya ukuran-ukuran kesehatan yang harus terpenuhi. Dalam penelitian yang dilakukan Kumar dan Taunk (2010), terkait kondisi toilet di sekolah dasar dan sekolah menengah di Uttarakhand India, terdapat beberapa aspek yang menjadi perhatian peneliti terkait kondisi kesehatan toilet tersebut. Aspek-aspek itu adalah aspek penggunaan toilet, aspek perawatan dan pengoperasian toilet, serta teknik konstruksi yang digunakan. Aspek penggunaan dan perawatan toilet yang telah disebutkan, dalam penelitian yang dilakukan oleh Harisah (2013), dikategorikan ke dalam aspek perilaku. Lebih lanjut, perilaku ini terpecah menjadi variabel yang berupa tingkat penggunaan kamar mandi, durasi penggunaan, jenis kegiatan yang dilakukan, kelengkapan fasilitas, hingga frekuensi membersihkan kamar mandi tersebut.

Penelitian lain yang mengangkat topik kesehatan di kamar mandi atau toilet adalah Ngabekti (2013). Aspek kesehatan yang ditelaah hanya terfokus pada dua hal, yaitu aspek kebersihan dan aspek kelancaran persediaan air di toilet tersebut. Hal ini sesuai dengan tuntutan WHO (2011 dalam Jurmang, 2013) bahwa sanitasi yang baik salah satunya dilihat dari fasilitas yang disediakan dan kelancaran pembuangan limbah manusia.

Penelitian selanjutnya yang mengangkat kesehatan kamar mandi sebagai kasus adalah penelitian yang dilakukan Murtini, et.al. (1994). Meskipun penelitian ini telah lama dilakukan, namun cakupan aspek kesehatan dari rancangan kamar mandi yang dibahas cukup dalam. Aspek kesehatan yang menjadi perhatian utama dalam penelitian ini adalah aspek kenyamanan ruang dalam kamar mandi, yang mencakup aspek ketersediaan ventilasi udara, pencahayaan alami, dimensi ruang dan persyaratan sanitasinya, berupa persediaan air bersih dan kelancaran pembuangan air kotor.

Ketersediaan pencahahayaan alami, yaitu sinar matahari, di kamar mandi sangat dibutuhkan karena berfungsi untuk mencegah meningkatknya kelembaban di kamar mandi, yang dapat menyebabkan pertumbuhan jamur dan kuman (HVAC\&R Nation, 2009). Demikian juga halnya dengan ketersediaan ventilasi. Ventilasi di kamar mandi sangat dibutuhkan karena merupakan saluran bertukarnya udara kotor dari dalam kamar mandi dengan udara bersih dari luar.

Dalam penerapannya, ventilasi di kamar mandi juga dapat diganti dengan teknologi exhaust fan. Bagaimanapun bentuknya, kamar mandi harus memiliki saluran udara ke luar (lihat Gambar 1). Hal ini terkait dengan tuntutan kesehatan manusia, 
yang membutuhkan udara bersih yang bebas dari kandungan zat berbahaya yang terdapat di kamar mandi seperti carbon dioksida, uap yang beracun, polutan dan zat berbau lainnya (Technical Data, 2010).
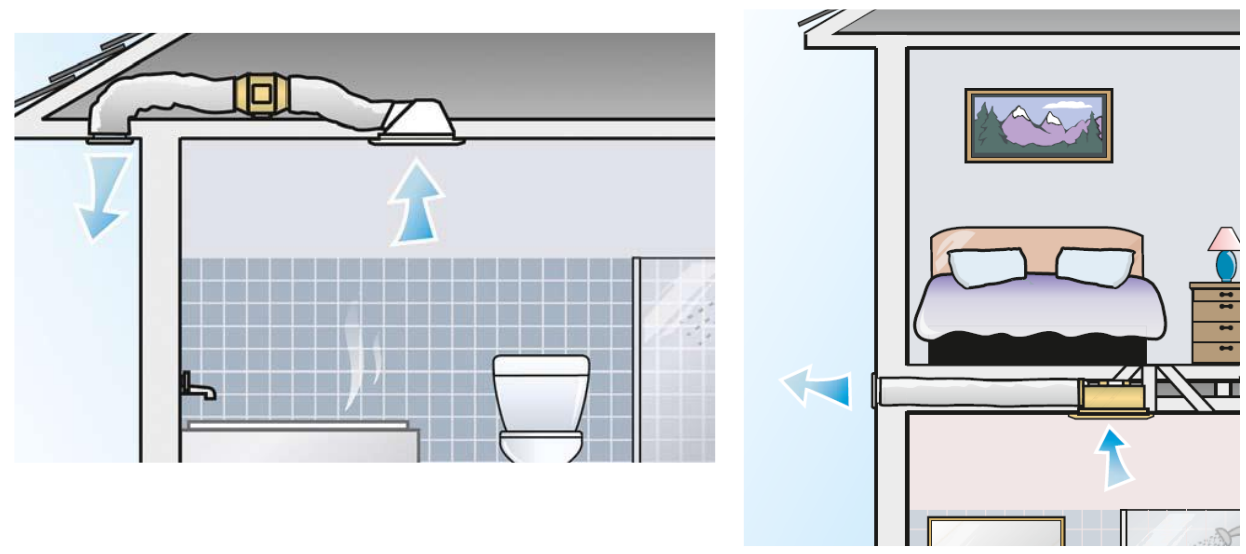

Gambar 1. Aliran Udara dari Dalam dan ke Luar Kamar Mandi melalui Penggunaan Exhaust Fan.

Sumber: www.clipsal.com

Sedangkan dari aspek dimensi ruang, kamar mandi memiliki batas minimum ruang yang harus dipenuhi untuk mencapai kriteria kamar mandi yang sehat. Untuk unit kamar mandi yang sekaligus WC, luas lantai minimum yang harus tersedia adalah 1,5 x 1,8 meter persegi. Sedangkan 1 unit kamar mandi saja, membutuhkan luas lantai $1 \times 2,2$ meter persegi untuk kamar mandi dengan shower dan $1 \times 1,9$ meter persegi untuk kamar mandi yang dilengkapi dengan bak air. Luas lantai kamar mandi minimum ini merupakan luas lantai yang bebas dari area sirkulasi, seperti arah bukaan pintu kamar mandi, sebagai mana pada Gambar 2 di bawah ini.
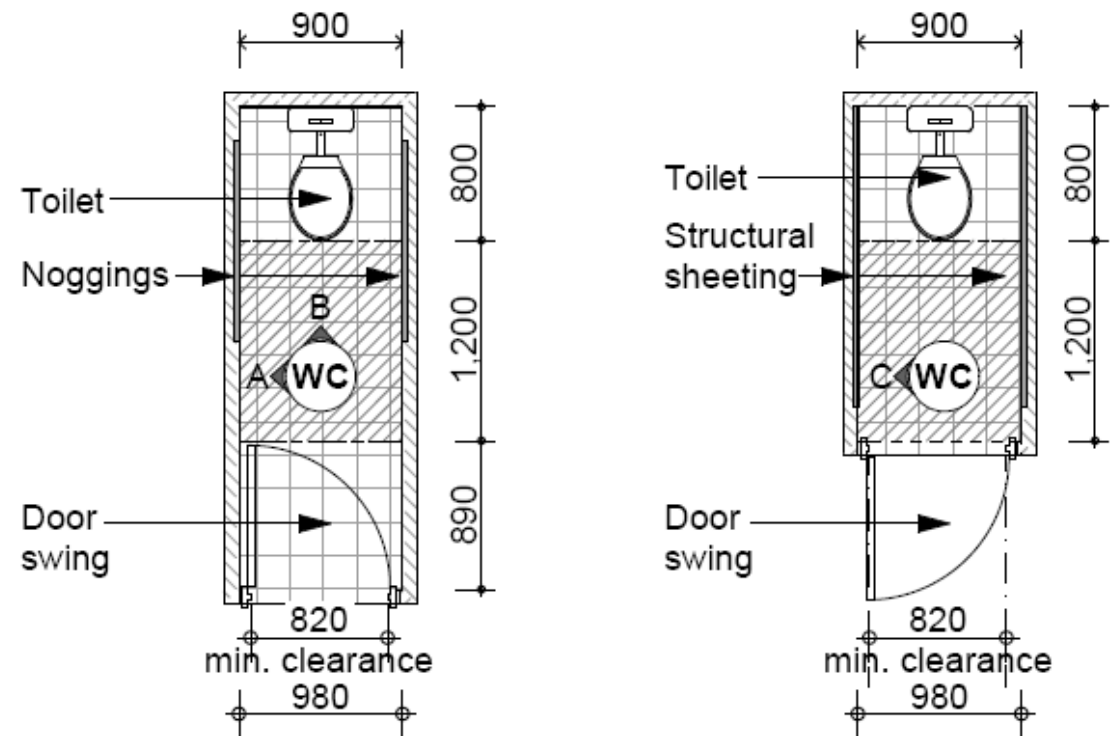

Gambar 2. Luas Lantai Minimum Bersih untuk Kamar Mandi dengan Shower.

Sumber: www.liveablehomes.net.au

Berdasarkan pembahasan tersebut, maka dapat dilihat bahwa terdapat beberapa aspek penting yang menjadi poin penting dalam menilai kualitas kamar mandi yang sehat. Aspek-aspek tersebut adalah sebagai berikut (lihat Tabel 1). 
Tabel 1. Aspek Penting dalam Melihat Kesehatan Desain Kamar Mandi

\begin{tabular}{ll}
\hline \multicolumn{1}{c}{ ASPEK } & \multicolumn{1}{c}{ SUMBER } \\
\hline Luas kamar mandi & www.liveablehomes.net.au \\
\hline Sirkulasi udara & Murtini, et.al. (1994). \\
\hline Penyinaran alami & Murtini, et.al. (1994). \\
\cline { 2 - 2 } & HVAC\&R Nation (2009) \\
\hline Kecukupan persediaan air bersih & Ngabekti (2013) \\
\hline Kelancaran saluran air kotor & Jurmang (2013) \\
\hline
\end{tabular}

\section{Studi Persepsi Tingkat Kesehatan Kamar Mandi Hunian Sewa Kos-Kosan Mahasiswa}

Persepsi (dari bahasa latin perceptio, percipio) adalah tindakan menyusun, mengenali, dan menafsirkan informasi sensoris guna memberikan gambaran dan pemahaman tentang lingkungan (Schacter, 2011). Persepsi meliputi semua sinyal dalam sistem saraf, yang merupakan hasil dari stimulasi fisik atau kimia dari organ pengindra. Persepsi, dengan demikian, adalah sebuah spontanitas yang bekerja secara kompleks di balik layar.

Meski demikian, persepsi bukanlah penerimaan isyarat secara pasif, tetapi dibentuk oleh pembelajaran, ingatan, harapan, dan perhatian. Dengan kata lain persepsi dibentuk oleh faktor internal dan eksternal (Ryan, 2013). Faktor internal dapat berupa perhatian, minat, kebutuhan, pengalaman dan ingatan, dan suasana hati. Sementara faktor eksternal yang mempengaruhi dan membentuk persepsi antara lain karakteristik lingkungan dan objek-objek yang terlibat di dalamnya.

Persepsi sering kali digunakan sebagai ukuran untuk melihat keberhasilan sebuah tindakan. Sebagaimana yang dilakukan oleh Harisah (2013) dalam menilai kualitas kamar mandi kos-kosan. Studi persepsi menjadi penting karena sering kali dengan memahami penilaian dari pengguna, yang berinteraksi langsung dengan objek studi dapat memberikan pemahaman baru terkait objek yang distudi. Oleh karena itu, studi persepsi dijadikan sebagai cara dalam melihat kualitas kamar mandi kos-kosan yang menjadi objek dalam penelitian ini, khususnya dari aspek kesehatan.

\section{METODOLOGI PENELITIAN}

Penelitian ini merupakan penelitian kuantitatif (Creswell, 2003). Data dikumpulkan menggunakan metode survei dengan kuesioner yang berisi pertanyaan yang bersifat tertutup (close-ended) yang disusun berdasarkan studi literatur yang menunjukkan variabel-variabel penting terkait aspek kesehatan dalam desain kamar mandi. Pertanyaan kuesioner dibagi ke dalam dua kelompok, yaitu pertanyaan 'ada' dan 'tidak ada' dan pertanyaan terkait 'tingkat kepuasan' terhadap kondiri kamar eksisting mandi. Dengan demikian, penelitian ini merupakan studi persepsi yang bertujuan untuk menggali kesesuaian antara kelengkapan atribut kesehatan kamar mandi dan penilaian pengguna kamar mandi terhadap tingkat kelayakan kesehatan kamar mandi tersebut.

Sampel penelitian dipilih dengan menggunakan metode non-random sampling yaitu menggunakan accidental sampling (Kumar, 2005). Data diambil dari 35 responden dengan menggunakan kuesioner online, dengan pertimbangan bahwa yang akan menjadi responden adalah mahasiswa ITB yang tinggal di hunian kos-kosan di sekitar kampus ITB, seperti di kawasan Cisitu, Dago, Tubagus, Pelesiran dan kawasan lain di sekitar kampus. 
Data yang diperoleh kemudian dianalisis dengan cara kuantitatif (Creswell, 2003), dengan menggunakan analisis distribusi dari kedua jenis pertanyaan. Analisis ini bertujuan untuk melihat bagaimana hubungan antara persepsi pengguna kamar mandi, yang dalam hal ini kamar mandi di unit kos-kosan, dengan kelengkapan atribut kesehatan yang seharusnya dimiliki oleh sebuah kamar mandi, sebagaimana yang telah dibahas sebelumnya. Kemudian dilakukan interpretasi terhadap data yang telah diperoleh.

\section{HASIL DAN PEMBAHASAN}

Total jumlah responden yang mengisi kuesioner online adalah 35 responden yang tinggal di berbagai lokasi hunian sewa kos-kosan di sekitar kampus ITB, yang tersebar di kawasan Dago, Kanayakan, Cisitu, Tubagus Ismail, Plesiran dan Ciheulang Baru. Kuesioner dibagi dalam 5 aspek permasalahan, yaitu aspek luas kamar mandi, aspek sirkulasi udara, aspek pencahayaan alami, aspek sanitasi dan aspek perilaku pengguna kamar mandi. Kelima aspek pertanyaan tersebut dibagi ke dalam dua bentuk pertanyaan, yaitu pertanyaan yang bersifat pilihan, seperti 'ada' dan 'tidak ada' dan pertanyaan yang bersifat skala, dengan rentang skala 1 sampai 5. Pertanyaan 'ada' dan 'tidak ada' bertujuan untuk menggali kondisi kelayakan kamar mandi yang sebagaimana mestinya di lapangan. Sedangkan pertanyaan skala bertujuan untuk melihat sejauh mana tingkat kepuasan responden terhadap kondisi eksisting tersebut.

Khusus untuk analisis aspek luas kamar mandi, dibutuhkan pengolahan data mentah terlebih dahulu sebelum dapat dianalisis dengan data lainnya. Data yang dikumpulkan dari kuesioner terkait pertanyaan luas kamar mandi dinyatakan dalam meter persegi (panjang x lebar). Sehingga dibutuhkan pengkategorisasian data terlebih dahulu ke dalam dua kategori, yaitu kategori yang memenuhi luas minimum dan kategori yang tidak memenuhi luas minimum kamar mandi.

Berdasarkan analisis distributif yang telah dilakukan terhadap kedua jenis pertanyaan dari masing-masing aspek kesehatan kamar mandi, diperoleh temuan sebagai berikut (lihat Tabel 2).

Tabel 2. Hasil Analisis Distribusi Data Semua Responden

\begin{tabular}{|c|c|c|c|c|}
\hline Aspek & Kelayakan & $\%$ & Kepuasan & $\%$ \\
\hline \multirow{5}{*}{$\begin{array}{l}\text { Luas kamar } \\
\text { mandi }\end{array}$} & \multirow[t]{3}{*}{ Layak } & \multirow[t]{3}{*}{68} & Sangat puas & 2,9 \\
\hline & & & Puas & 41 \\
\hline & & & Netral & 44 \\
\hline & \multirow[t]{2}{*}{ Tidak layak } & \multirow[t]{2}{*}{32} & Tidak puas & 11,8 \\
\hline & & & Sangat tidak puas & 0 \\
\hline \multirow{10}{*}{ Sirkulasi udara } & \multirow[t]{3}{*}{ Ada } & \multirow[t]{3}{*}{70} & Sangat puas & 9 \\
\hline & & & Puas & 26 \\
\hline & & & Netral & 32 \\
\hline & \multirow[t]{2}{*}{ Tidak ada } & \multirow[t]{2}{*}{30} & Tidak puas & 32 \\
\hline & & & Sangat tidak puas & 0 \\
\hline & \multirow[t]{3}{*}{ Bau } & \multirow[t]{3}{*}{65} & Sangat sering & 5 \\
\hline & & & Puas & 32 \\
\hline & & & Netral & 14 \\
\hline & \multirow[t]{2}{*}{ Tidak bau } & \multirow[t]{2}{*}{35} & Tidak puas & 36 \\
\hline & & & Sangat tidak sering & 14 \\
\hline \multirow{2}{*}{ Penyinaran alami } & \multirow[t]{2}{*}{ Ada } & \multirow[t]{2}{*}{53} & Sangat puas & 12 \\
\hline & & & Puas & 38 \\
\hline
\end{tabular}




\begin{tabular}{|c|c|c|c|c|}
\hline Aspek & Kelayakan & $\%$ & Kepuasan & $\%$ \\
\hline & & & Netral & 21 \\
\hline & Tidak ada & 47 & Tidak puas & 18 \\
\hline & & & Sangat tidak puas & 11 \\
\hline \multirow{5}{*}{$\begin{array}{l}\text { Kecukupan } \\
\text { persediaan air }\end{array}$} & \multirow[t]{3}{*}{ Cukup } & \multirow[t]{3}{*}{94} & Sangat puas & 29 \\
\hline & & & Puas & 59 \\
\hline & & & Netral & 8 \\
\hline & \multirow[t]{2}{*}{ Tidak cukup } & \multirow[t]{2}{*}{6} & Tidak puas & 3 \\
\hline & & & Sangat tidak puas & 0 \\
\hline \multirow{5}{*}{$\begin{array}{l}\text { Kelancaran } \\
\text { saluran air kotor }\end{array}$} & \multirow[t]{3}{*}{ Lancar } & \multirow[t]{3}{*}{76} & Sangat puas & 31 \\
\hline & & & Puas & 46 \\
\hline & & & Netral & 19 \\
\hline & \multirow[t]{2}{*}{ Tidak lancar } & \multirow[t]{2}{*}{24} & Tidak puas & 4 \\
\hline & & & Sangat tidak puas & 0 \\
\hline
\end{tabular}

Berdasarkan tabel 1 di atas, terlihat bahwa aspek kecukupan persediaan air bersih menjadi aspek yang paling terpenuhi di kamar mandi hunian kos-kosan. Hal ini terbukti dari sebesar 94\% dari total responden menyatakan bahwa memiliki persediaan air bersih yang cukup. Sedangkan aspek luas kamar mandi, sirkulasi udara, kelancaran saluran air kotor dan aspek tidak ditemukannya akses serangga memperoleh persentase yang cukup baik, yaitu besar dari $60 \%$ dari total responden menyatakan setiap aspeknya terpenuhi dengan baik di kamar mandi. Selanjutnya, untuk aspek pencahayaan alami di kamar mandi memperoleh persentase yang paling rendah terkait terpenuhinya kebutuhan pencahayaan alami tersebut. Hal ini terlihat dari tabel 1 bahwa hampir 50\% responden menyatakan bahwa pencahayaan alami tidak ditemukan di kamar mandi hunian sewa mereka.

Dari data persentase kelayakan (terpenuhinya kriteria kesehatan dari beberapa aspek tersebut), kemudian dilihat bagaimana respon responden terhadap kualitas dari setiap aspek. Pertanyaan ini merupakan pertanyaan terkait persepsi penghuni terhadap kondisi kesehatan kamar mandi sebagaimana yang telah dijelaskan sebelumnya. Dari aspek kecukupan persediaan air bersih, yang sebesar $94 \%$ responden menyatakan persediaan air bersih di kamar mandi mereka cukup, ditemukan bahwa hampir $90 \%$ responden memberikan respon yang baik terhadap tingkat kepuasan persediaan air bersih (59\% menyatakan puas dan $29 \%$ menyatakan sangat puas). Hal ini menunjukkan adanya kesesuaian antara aturan-aturan yang berlaku dengan pemahaman dan kebutuhan responden terkait air bersih.

Kesesuaian kriteria dengan persepsi responden ini juga terjadi pada aspek pencahayaan alami dan kelancaran saluran air kotor. Terpenuhinya aspek pencahayaan alami sebesar $50 \%$, sesuai dengan persepsi responden yang dinyatakan dengan angka 50\% menunjukkan rasa puas (38\% puas dan $12 \%$ sangat puas). Demikian juga halnya dengan aspek kelancaran saluran air kotor. Sebesar 76\% responden menyatakan saluran air kotor di kamar mandi mereka lancar. Hal ini juga dibuktikan dengan tingkat kepuasan responden sebesar $77 \%$ menyatakan puas (46\% puas dan $31 \%$ sangat puas).

Hal berbeda terjadi pada dua aspek lainnya, yaitu aspek luas kamar mandi dan aspek sirkulasi udara. Sebesar 68\% responden menyatakan bahwa luas kamar mandi mereka memenuhi luar minumum kamar mandi hunian. Akan tetapi, dari tingkat kepuasan, hanya ditemukan $44 \%$ yang menyatakan puas terhadap luas kamar mandi tersebut. Sedangkan $44 \%$ lainnya menyatakan netral dan $12 \%$ lainnya menyatakan tidak puas. Berdasarkan hal ini, dapat dipahami bahwa terdapat aspek lain yang mempengaruhi tingkat kepuasan responden terhadap luas kamar mandi di unit kos-kosan. Hal ini mungkin saja dipengaruh oleh kapasitas pengguna yang ditampung oleh unit kamar mandi tersebut. Hal ini terlihat dari $37 \%$ responden menyatakan menggunakan kamar mandi secara bersamaan dengan penghuni lainnya.

Aspek lain yang ditemukan tidak sesuai antara data kelayakan dan persepsi penghuninya adalah aspek sirkulasi udara. Dari hasil kuesioner terlihat bahwa sejumlah $70 \%$ responden 
menyatakan memiliki sirkulasi udara ke luar hunian. Akan tetapi, hanya 35\% dari keseluruah responden yang menyatakan puas dengan sirkulasi udara dan hanya 50\% responden yang menyatakan sangat jarang mencium bau yang tidak enak dari kamar mandi mereka. Hal ini juga menunjukkan bahwa pertanyaan 'ada' atau 'tidak ada' saja tidak cukup untuk menilai kelayakan sebuah kamar mandi. Diperlukan adanya telaah lebih lanjut mengenai kategori tersebut. Dari $70 \%$ responden yang menyatakan memiliki sirkulasi udara keluar, ditemukan bahwa $88 \%$ responden menyatakan bahwa kamar mandinya menggunakan ventilasi sebagai saluran udara keluar masuk kamar mandi mereka. Berdasarkan penyataan tersebut, perlu telaah lebih dalam terkait besaran ventilasi dan kriteria lain yang menyangkut kelancaran sirkulasi udara dari dan ke dalam kamar mandi.

\section{KESIMPULAN}

Berdasarkan pembahasan tersebut, terdapat tujuh aspek yang menjadi kriteria kamar mandi yang sehat. Aspek-aspek tersebut adalah luas kamar mandi, sirkulasi udara langsung ke luar unit hunian, pencahayaan alami, kecukupan persediaan air bersih, dan kelancaran saluran air kotor. Kehadiran aspek-aspek tersebut merupakan penentu terpenuhinya kriteria sehat dari sebuah kamar mandi.

Dari hasil kuesioner yang telah disebar kepada 35 responden, dapat dipahami bahwa pada desain hunian sewa kos-kosan, telah ditemukan adanya perhatian yang cukup baik terhadap kelima aspek aspek yang mendukung terciptanya kamar mandi yang sehat. Hal ini terlihat dari lebih dari 50\% responden menyatakan bahwa kamar mandi kos-kosan mereka telah memiliki setiap aspek kesehatan yang tertera dalam kriteria desain kamar mandi yang sehat. Akan tetapi, diperlukan adanya telaah lebih lanjut mengenai bagaimana pemenuhan aspek-aspek tersebut dilakukan. Hal ini dapat dilihat melalui indikator tingkat kepuasan penghuni hunian sewa tersebut. Jika ditemukan adanya tingkat kepuasan yang kurang, maka dipercaya adanya pengaruh faktor lain yang bekerja pada aspek tersebut. Seperti misalnya faktor kapasitas tampung dari satu unit kamar mandi dan aspek besaran ventilasi dari sebuah kamar mandi yang sehat.

\section{DAFTAR PUSTAKA}

Burton, S. 2013. Toilets Unblocked: A Literature Review of School Toilets. Scotland's Commissoner for Children \& Young People (SCCYP).

Creswell, J.W. 2003. Research Design: Qualitative, Quantitative, and Mixed Methods Approaches. California: SAGE Publications, Inc.

Harisah, A. 2013. Kamar Mandi Untuk Mahasiswa Indekos: Sebuah Studi Pola Perilaku, Kebutuhan, dan Setting Fisik. Prosiding Temu Ilmiah IPLBI.

Jurmang, I.,C. 2013. Social Studies for Awareness of Toilet Facilities in Jos to Achieve Environmental Sanitation. Mediterranean Journal of Social Sciences. Vol. 4, no. 15. Rhome-Italy: MCSRER Publishing.

Kumar, A., \& Taunk, A. 2010. A Study of Sanitation of Toilets in Elementary School and Senio High Schools Located in Rural Areas of Uttarakhand in India. International Journal of Sociology and Anthropology. Vol. 2(8), hal. 178-184. ISSN 2006-988x.

Kumar, Ranjit. 2005. Research Metodology, A Step by Step Guide for Beginner. Londoh: Sage Publications.

Kusumarini, Y. \& Utomo,T.N.P. 2008. Konsep Desain Kamar Mandi Bertema "Accessible Restroom" 2007: Analisis Penerapan Konsep "Desain Universal" pada Sayembara Perancangan. Journal Visual Art \& Desain ITB. Vol.2, No. 1, hal. 85-98.

Murtini, et.al. 1994. Kajian Perancangan Kamar Mandi Rumah Tinggal. Laporan Akhir Hasil Kegiatan Penelitian Perguruan Tingi Fakutas Teknik Diponegoro.

Ryan, K.,O.,P. 2013. Pengaruh Pendidikan Kesehatan terhadap Perubahan Pengetahuan, Sikap dan Perilaku tentang Kebiasaan Hidup Bersih dan Sehat Siswa 1 Mandong.

Fakultas Ilmu Kesehatan Universitas Muhammadiya Surakarta.

Schacter, D. 2011. Perception in Psychology. Worth Publisher.

Internet 
PENA TEKNIK: Jurnal Ilmiah Ilmu-Ilmu Teknik

Volume 3, Nomor 2, September 2018: 169 - 176

HVAC\&R Nation. 2009. www.hvacrnation.au. Diakses pada tanggal 10 Oktober 2015, pukul 15.00 WIB.

Scheider Electric: A Fan for All Seasons. Technical Data. 2010. www.clipsal.com. Diakses pada tanggal 10 Oktober 2015, pukul 16.00 WIB. 